\title{
NILAI SOSIAL DALAM NOVEL YOGYAKARTA KARYA DAMIEN DEMATRA DAN RELEVANSINYA SEBAGAI MATERI AJAR DI SMA: KAJIAN SOSIOLOGI SASTRA
}

\author{
Fitri Yani $^{1}$, Imam Muhtaron ${ }^{2}$, dan Sahlan Mujtaba ${ }^{3}$ \\ Program Studi Pendidikan Bahasa dan Sastra Indonesia - Fakultas Keguruan dan \\ Ilmu Pendidikan - Universitas Singaperbangsa Karawang ${ }^{1,2,3}$ \\ Surel pitriyuli4@gmail.com ${ }^{1}$ \\ imam.muhtarom@fkip.unsika.co.id ${ }^{2}$ \\ sahlan.mujtaba@fkip.unsika.ac.id ${ }^{3}$
}

\begin{abstract}
Abstrak
Penelitian ini dilatarbelakangi oleh lunturnya nilai-nilai sosial di kalangan generasi muda atau kalangan pelajar. Tujuan pembuatan artikel untuk mendeskripsikan kajian nilai sosial. Penelitian ini merupakan penelitian kualitatif. Penelitian ini mendeskripsikan nilai-nilai sosial dalam novel Yogyakarta karya Damien Dematra. Hasil analisis nilai sosial dalam novel Yogyakarta karya Damien Dematra ditemukan 26 data yang dikelompokan menjadi delapan aspek, yaitu aspek nilai pengabdian, nilai tolongmenolong, nilai kekeluargaan, nilai kesetiaan, nilai kepedulian, nilai disiplin, nilai toleransi setra nilai empati. Penelitian ini direlevansikan sebagai materi ajar di Sekolah Menengah Atas pada materi novel kelas XII Kompetensi Dasar (KD).
\end{abstract}

Kata Kunci: Nilai sosial, Novel, Materi Ajar, Teknik Studi Kepustakaan, Teknik Baca Catat.

\section{Abstract}

This research has backgrounds about the loss of social value on young or student generation. The purposelofimaking this Thesis for: This research is a qualitative research. This research describes social values in the novel Yogyakarta by Damien Dematra. a social value analysis in Damien Dematra Novel Yogyakarta found 26 data grouping into eight aspects, which are an aspect of the value of devotion, a sense of helpfulness, a sense of brotherhood, the value of loyalty, the value of concern, the value of compassion, the value of tolerance and the value of empathy. the research has relevance as teaching material in Senior High School in the novel material of class XII Basic Competency (KD) 3.9 Analyzing the contents and language of the novel WITH Competency achievment indicators (GPA) 3.9.1 Finding novel intrinsic and extrinsic elements. 
Keywords: Social Values, Novels, Teaching Materials Library Study

Technique, Note Taking Tehnique

\section{PENDAHULUAN}

Seiring dengan perkembangan zaman, diera globalisasi ini nilai-nilai kepedulian sosial terus mengalami penurunan khususnya di kalangan generasi muda atau kalangan pelajar. Nilai-nilai kepedulian sosial yang saat ini mulai luntur contohnya sikap tidak bertanggung jawab, tidak disiplin, tidak memiliki empati, tidak saling tolong menolong, rasa kekeluargaan yang kurang, tidak peduli kepada sesama, sikap ingin menang sendiri, tidak setia kawan, dan lain sebagainya

Dari lunturnya nilai-nilai tersebut muncullah masalah-masalah sosial seperti tidak ada rasa kepedulian, jauh dari agama sehingga menyebabkan munculnya tindakan seperti membolos sekolah, melanggar peraturan-peraturan sekolah, mem-bully sesama teman, perkelahian antara geng atau sekolah, penggunaan obat-obat terlarang dan sebagainya. Penyebab lunturnya nilainilai tersebut sangat beragam, di antaranya karena kesenjangan sosial atau status sosial, atau kondisi kebahagiaan dan ketentraman keluarga yang semakin terancam bahaya. Keadaan itu disebabkan kesalahán mengartikan dan menerapkan rasa kasih sayang maupun bagaimana caranyă memelihara cinta kasih dalam keluarga.

Setiap jenis masalah memiliki solusi yang berbeda-beda dalam penanganannya. Dari fenomena dan masalah-masalah sosial tersebut dapat diatasi dengan memperkenalkan sastra kepada siswa, karena pada zaman modern sekarang ini, kedudukan sastra semakin meningkat dan semakin penting. Sastra tidak hanya memberikan kenikmatan membaca dan kepuasan batin, tetapi juga sebagai sarana penyampaian pesan moral kepada masyarakat atas realita sosial. Karya sastra sebagai potret kehidupan bermasyarakat merupakan suatu karya sastra yang dapat dinikmati, dipahami, dan dapat dimanfaatkan oleh masyarakat.

Karya sastra yang dapat memberikan pembelajaran sosial kepada siswa salah satunya yaitu novel. Menurut Nurgiantoro (2013: 9) menyatakan bahwa, "Novel adalah karya sastra yang mengungkapkan aspek-aspek kemanusiaan yang lebih mendalam dan disajikan dengan halus." Novel merupakan salah satu karya sastra yang berisi berbagai peristiwa yang dialami oleh tokoh secara sistematik dengan menampilkan unsur cerita paling lengkap.

Novel mempunyai tugas yang penting sebagai bahan bacaan yang dapat memberi pengaruh moral atau nilai yang positif bagi pembacanya. Nilai atau amanat pada novel dibutuhkan dalam pembelajaran mengingat beberapa tahun terakhir fenomena pergantian kurikulum yang berubah-ubah dalam kurun waktu yang siingkat. Akan tetapi perubahanperubahan ${ }^{\text {Sastro }}$ kurikulum tersebut pemerintah Indonesia bermaksud baik dengan tujuan memiliki mutu pendidikan yang lebih berkarakter.

Salah satu novel yang dapat diambil pembelajarannya yaitu novel Yogyakarta karya Damien Dematra. Novel ini Novel ini mengisahkan kehidupan empat pemuda dari empat daerah berbeda yang merantau untuk meraih impiannya, mencari jati diri dan menguraikan masalah hidupnya 
masing-masing. Mereka datang ke Yogyakarta untuk melanjutkan studinya. Tema dalam novel ini sangat dekat dengan masyarakat dan dapat dibaca oleh semua kalangan. Masalah yang diangkat dalam novel ini pun sangat dekat dengan masyarakat sehingga bisa dijadikan pembelajaran sastra di sekolah.

Pentingnya meneliti nilai sosial dalam novel Yogyakarta karya Damien Dematra yaitu bertujuan agar siswa memiliki kemampuan menghayati, memahami, dan menikmati serta menilai karya sastra yang dibacanya. Setelah usaha itu dilakukan siswa diharapkan dapat mengambil manfaat dari karya sastra yang dibacanya. Siswa diharapkan akan meneladani sikap dan nilai-nilai kehidupan yang positif dari para tokoh yang ada di dalam novel tersebut.

Berdasarkan alasan tersebut, penulis merumuskan permasalahan: (1) Apa saja nilai-nilai sosial yang terkandung dalam novel Yogyakarta karya Damien Dematra? dan (2) Apa penyusunan materi ajar yang terkandung dalam novel Yogyakarta karya Damien Dematra? Tujuan dalam penelitian ini adalah (1) mendeskripsikan nilai-nilai sosial dalam novel Yogyakarta karya Damien Dematra. (2) mendeskripsikan penyusunan materi ajar dalam novel Yogyakarta karya Damien Dematra.

\section{METODE}

Penelitian ini menggunakan metode kualitatif. Menurut Moleong (2011, hlm. 6) penelitian kualitatif adalah penelitian yang bermaksud untuk memahami fenomena tentang apa yang dialami oleh subjek penelitian misalnya perilaku, persepsi, motivasi, tindakan dan lain-lain secara holistik dan dengan cara deskripsi dalam bentuk kata-kata dan bahasa, pada suatu konteks khusus yang alamiah dengan memanfaatkan berbagai metode ilmiah. Sumber data dalam penelitian ini adalah novel Yogyakarta karya Damien Dematra yang diterbitkan oleh Gramedia Pustaka Utama pada tahun 2011 dengan jumlah 258 halaman. Data dalam penelitian ini adalah kalimat-kalimat ataupun ujaranujaran yang mengandung nilai-nilai sosial.

Teknik pengumpulan data dalam penelitian ini adalah teknik studi pustaka. Studi pustaka dilakukan untuk mendapatkan bahan-bahan dan informasi yang berhubungan dengan penelitian seperti buku-buku, artikel, dokumen-dokumen yang berkaitan dengan penelitian. Langkah-langkah analisis data yang digunakan dalam penelitian ini, yaitu: (1) Membaca novel Yogyakarta karya Damien Dematra secara keseluruhan dengan cermat. (2) Mengumpulkan dan mengklasifikasikan data yang dianggap sesuai dengan nilai sosial. (3) Menganalisis data yang telah diklasifikasikan sesuai pedoman analisis yang telah ditentukan. (4) Mengimplementasikan kajian terhadap pembelajaran sastra di Sekolah Menengah Atas (SMA) Berdasarkan hasil analisis.

\section{HASIL DAN PEMBAHASAN}

Menurut Zubaedi (2005, hlm. 13) nilai-nilai sosial dibagi atas beberapa sub nilai, yang pertama yaitu Loves (kasih sayang) yang terdiri atas pengabdian, kekeluargaan, tolongmenolong, kepedulian, dan kesetiaan. Kedua, Responsibility (tanggung jawab) yang terdiri atas nilai rasa memiliki, empati, dan disiplin. Dan ketiga adalah nilai Life Harmony (keserasian hidup) 
yang terdiri atas nilai keadilan, kerjasama, toleransi, dan demokrasi. Namun setelah penulis melakukan penelitian di dalam novel Yogyakarta karya Damien Dematra didapatkan nilai-nilai sosial sebagai berikut.

Menurut Wellek dan Werren (2016, hlm. 100) terdapat tiga jenis pendekatan yang berbeda dalam sosiologi sastra.

a. Sosiologi pengarang yang berkaitan dengan masalah dasar ekonomi sastra, status pengarang, latar belakang sosial, dan ideologi pengarang di luar karya sastra.

b. Sosiologi karya yang berkaitan dengan isi, tujuan, dan hal-hal yang tersirat dalam karya sastra itu sendiri yang berhubungan dengan masalah sosial.

c. Sosiologi pembaca berkaitan dengan masalah pembaca dan dampak sosial karya sastra.

Penelitian ini menggunakan sosiologi sastra yang mempermasalahkan karya sastra itu sendiri yaitu mengungkapkan isi, tujuan, dan hal-hal yang tersirat dalam karya karya sastra itu sendiri yang berhubungan dengan masalah sosial.

\section{Pengabdian}

Pengabdian merupakan perbuatan baik berupa pikiran, pendapat ataupun tenaga sebagai perwujudan kesetiaan, cinta, kasih sayang, hormat, atau suatu ikatan, dan semua itu dilakukan dengan ikhlas. Bentuk pengabdian seperti pengabdian kepada Allah Swt., Pengabdian kepada keluarga, serta pengabdian kepada masyarakat.

"Bedhen kaule pijat, Pak? Enak, pagi-pagi, hari Minggu begini," kata Istrinya lagi, berusaha yang terbaik karena ia tahu sepasang mata bulat dari seorang anak sedang menatapnya dengan penuh perhatian" (Dematra, 2010, hlm. 35).

Kutipan di atas menggambarkan bagaimana Siti Arum menawarkan kepada suaminya untuk dipijat. Selain karena ia harus mengabdi kepada suaminya, ia harus memperlihatkan kepada anaknya bahwa hubungan orang tuanya memang baik-baik saja. Hal seperti itu memang menjadi salah satu di antara kewajiban seorang istri atas suaminya. Hendaknya seorang istri benar-benar menjaga amanah suami di rumah, baik harta suami dan rahasiarahasianya. Begitu juga bersungguhsungguh menurus urusan-urusan rumah tangga.

\section{Kekeluargaan}

Keluarga adalah sekumpulan orang yang tinggal dalam satu rumah yang yang masih mempunyai hubungan kekerabatan/hubungan darah karena perkawinan. Sedangkan kekeluargaan adalah sikap manusia satu sama lain saling peduli dan menyanyi walaupun bukan tidak memiliki hubungan darah.

"Gerson tersenyum, kemudian menatap ke halaman belakang. Ia selalu merasa nyaman bersama perempuan tua bertubuh kecil ini, seperti antara ibu dan anak". (Dematra, 2010, hlm. 24).

Kutipan tersebut terlihat bahwa rasa kasihaesayang kekeluargaan seorang bude sama seperti rasa sayang seorang ibu kepada anaknya. Saat terjadi hal-hal buruk terhadap seorang anak, tentulah orang tua terutama ibu yang merasakan rasa khawatir yang luar biasa. Rasa khawatir itu membuat Gerson merasa nyaman bersama Ananda. Hal itu membuktikan bahwa seseorang dapat membuat kita merasa nyaman atas perlakuan dan perhatiannya. 


\section{Tolong-menolong}

Tolong menolong adalah membantu meringankan beban penderitaan, kesukaran melakukan sesuatu, menyelamatkan, dan melepaskan diri dari bahaya ataupun bencana.

"Yesaya akhirnya juga menampung Maria yang lebih banyak menghabiskan hari-harinya dengan berdiam diri, dan setiap hari, Gerson berusaha menghiburnya dengan berbagai macam cara." (Dematra, 2010, hlm. 10)

Kutipan di atas menjelaskan bahwa adanya hubungan interaksi yang baik antara sesama warga masyarakat khususnya di saat ada seseorang yang butuh pertolongan. Tokoh Yesaya saling menolong untuk membantu ibu Gerson dan Gersonnya untuk sementara tinggal di rumahnya sampai keadaan serangan antar agama itu selesai. Hikmah yang dapat diambil dari kutipan di atas adalah, sebagai makhluk sosial kita harus saling tolongmenolong. Contohnya ketika sedang menghadapi musibah.

\section{Kepedulian}

Kepedulian merupakan salah satu bentuk tindakan nyata yang dilakukan oleh masyarakat dalam merespon suatu permasalahan serta memiliki perrasaản bertanggung jawab terhadap kesulitan yang dihadapi orang lain dimana seseorang terdorong untuk melakukan suatu kebaikan dalam rangka mebantunya.

"Gerson memeluk tubuh laki-laki yang dikenalnya sebagai Yesaya Yousaf, tetangga sebelahnya, seorang duda tua yang karaya. Sebagian rambutnya telah memutih namun tubuhnya masih kuat. Laki-laki itu menggotongnya ke rumahnya sendiri dan mengganti celananya yang basah, kemudian memeluknya yang menggigil ketakutan seharian" (Dematra, 2010, hlm. 21).

Pada kutipan di atas menggambarkan bagaimana sikap kepedulian tokoh Yesaya Yousaf memiliki kepedulian terhadap sesama, hal itu digambarkan dalam kutipan di atas, dimana Yesaya Yousef mengajak Gerson dan Ibunya yang rumahnya hancur terkena pembantaian untuk tinggal sementara di rumahnya. Sikap tersebut sangat baik untuk diterapkan atau diaplikasikan di kalangan masyarakat. Hal tersebut menggambarkan betapa kuatnya rasa kepedulian Yayesa Yousaf, ketika langsung menolong apa yang dibutuhkan oleh orang lain dan mengekspresikan menjadi sebuah tindakan.

\section{Kesetiaan}

Kesetiaan adalah orang yang berpendirian teguh, taat dengan perjanjian atau keputusan hasil musyawarah bersama, taat pada orangtua, keluarga, suku dan bangsa, dan tidak mudah terbujuk oleh orang lain atau harta.

"Yahya merasa ia mengetahuinya. Setiap denyut nadinya masih merindukan Monalisa, dan semakin lama ia berpisah dengan perempuan itu semakin terasa sebuah kepedihan yang dalam.'(Dematra, 2010, hlm. 120).

Pada kutipan di atas menunjukan adanya rasa kesetiaan seorang Yahya kepada pacar masa lalunya. Meskipun mereka telah berpisah, Yahya merasa bahwa semakin lama ia berpisah semakin terasa sebuah kesedihan akan perpisahan tersebut, hal itu karena rasa 
sayang dan cinta Yahya yang masih membekas di hatinya. Kesetiaan yang kepada Monalisa tidak hilang hanya karna mereka sudah putus dan tidak bertemu.

\section{Empati}

Empati adalah kemampuan kita dalam menyelami perasaan orang lain tanpa harus tenggelam di dalamnya. Empati adalah kemampuan kita dalam mendengarkan perasaan orang lain tanpa harus larut. Empati merupakan kemampuan kita dalam merespon keinginan orang lain yang tak terucap.

"Setiap mahasiswa yang terlihat riang dan baik-baik itu sebenarnya memiliki masalah, pikirnya. Ia dapat merasakannya. Bukannya ia suka mencampuri kehidupan orang lain, namu ia selalu merasa bahwa dirinya dilengkapi dengan suatu kemampuan sebuah kepekaan." (Dematra, 2010, hlm. 12).

Nilai empati ditunjukan oleh Ananda kepada anak-anak kosnya. Ananda yang mempunyai sikap tegas dalam hal ini ia mempunyai kelembutan hati dan peduli dengan anak-anak kosnya. Ia tahu bahwa dibalik sikapsikap riang yang ditunjukan anak-anak kosnya mereka mempunya masalahmasalah. Ananda dapat merasakan hal tersebut. Ia merasa juga harus membantu permasalahan yang rasakan oleh anak-anak kosnya. Ia ingin merasa berguna dan ingin menjadi orang tua pengganti saat mereka yang jauh dari keluarga.

\section{Disiplin}

Tindakan yang menunjukan perilaku tertib dan patuh pada berbagai ketentuan dan peraturan dalam disiplin ada tiga unsur yang penting, yaitu hukum atau peraturan yang berfungsi sebagai pedoman penilaian, saksi atau hukuman bagi pelanggaran peraturan itu, dan hadiah untuk perilaku atau usaha yang baik.

Ibu kosnya cuma minta gue sarapan setiap jam 6.15 dan pulang sebelum jam 10 malem, kecuali Sabtu. Kalau gue mau ngajak temen nginep, harus ngasih tau satu hari sebelumnya. Yah, standarlah, yang lainnya." (Dematra, 2010, hlm. 79).

Dalam kutipan diatas menggambarkan bagaimana penguni kos mulai mengikuti peraturan yang Ananda buat di kosannya salah satunya yaitu harus disiplin, sifat itu kemudian mulai dilakukan oleh anak kosnya, salah satunya yaitu Olivia, ia yang dari Jakarta bebas sesuka hati pulang jam malam. Di Yogyakarta ia harus pulang sebelum jam 10 malam dan ia melakukannya dan memberi tahu kepada temannya yang di Jakarta jika ingin menginap di kosnya.

\section{Toleransi}

Pada intinya toleransi bersifat dan bersikap menghargai. Sifat dan sikap menghargai harus ditunjukan oleh siapapun terhadap bentuk pluralitas yang ada di Indonesia. Maka dari itu, idkita saling menghargai toleransi yang ada dipl, Indonesia karena, dengan toleransi kita dapat mengenal satu sama lain.

"Aku kenal ayah dan ibumu dengan sangat baik. Kita bertetangga pula. Sudah jadi kewajibanku untuk menolong kalian, aku berdosa pada Tuhan apabila tidak melakukannya."

"Tapi aku orang Isalm. Oom orang Kristen, dan Papa... Papa meninggal karena perusuh-perusuh 
Nasrani." Ia merasa galau. pembelajaran bahasa dan sastra

Batinnya berperang hebat. Indonesia penting diterapkan untuk

(Dematra, 2010, hlm. 22).

Nilai toleransi yang terdapat dalam kutipan tersebut adalah adanya saling menghargai meskipun mereka berbeda agama. Saat tokoh Tarjo menanyakan kepada Bude apa agama Olivia, dan Tarjo tidak mempermasalahkan agama yang dianut oleh Olivia, ia merasa bahwa ini adalah kota Yogyakarta, kota pelajar yang banyak pelajar dari berbagai kota-kota di Indonesia. Pasti banyak perbedaanya dan rasa toleransi yang kuat. Selain itu terdapat pula nilai toleransi lainnya.

Dalam kaitannya dengan pendidikan, implikasi karya sastra dapat dilakukan melalui pembelajaran bahasa dan sastra Indonesia. Kurikulum 2013 untuk kelas XII SMA/MA terdapat KD pembelajaran sastra melalui media novel. Hal tersebut tertuang dalam KD 3.9 Mengidentifikasi butir-butir penting dari dua buku nonfiksi (buku pengayaan) dan satu novel yang dibacakan nilai-nilai dan kebahasaan cerita. Kompetensi dasar ini diajarkan pada semester ganjil kelas X. Hal ini karena pada rumusan kompetensi ke-2, yaitu tentang sikap sosial "menunjukan perilaku jujur, disiplin, tanggung jawab, peduli (gotong-royong, kerja sama, toleran, damai), santun, responsif, ',àn proaktif, sebagai bagian dari solusi atas berbagai permasalahan dalam berinteraksi secara efektif dengan lingkungan sosial dan alam serta menempatkan diri sebagai cerminan bangsa dalam pergaulan dunia (Kemendikbud, 2017, hlm. 1)". Dari kutipan sebelumnya, tampak jelas bahwa tujuan perumusan KD ke-2 setiap mata pelajaran harus mengarah kepada pembentukan karakter sikap sosial. hal ini menunjukan menanamkan nilai-nilai sosial. melalui sastra, nilai sosial yang terkandungnya dapat dijadikan pembelajaran nilai-nilai sosial baik di sekolah maupun di luar sekolah. Untuk itu, pembelajaran sastra dapat diterapkan di sekolah, yaitu untuk menanamkan nilai-nilai sosial melalui novel Yogyakarta karya Damien Dematra.

\section{PENUTUP}

\section{Simpulan}

Berdasarkan hasil penelitian yang telah dilakukan oleh penulis pada novel Yogyakarta karya Damien Dematra dapat disimpulkan terdapat tujuh nilai sosial. Pertama yaitu Sikap pengabdian terwujud dalam bentuk tindakan tokohtokoh secara nyata. Tokoh Tarjo yang mengabdi kepada Allah dengan membaca dan menghafal Al-Quran. Kedua sikap tolong menolong terwujud dari tokoh Yesaya yang membantu Gerson untuk tinggal dahulu di rumah Yesaya. Ketiga sikap kekeluargaan terwujud dari tokoh Ananda yang menganggap mahasiswa yang tinggal di kosan patut disayang seperti keluarga sendiri. Keempat sikap kesetiaan terwujud oleh sikap Yahya kepada ipacar masa lalunya, meskipun mereka artelah berpisah, perasaan Yahya masih untuk Monalisa pacarnya masalalunya. Kelima yaitu sikap kepedulian yang terwujud oleh tokoh Yesaya yang mengajak Gerson dan ibunya korban pertikaian antar agama untuk tinggal di rumahnya. Keenam nilai disiplin yang diperlihatkan oleh sikap Ananda kepada anak-anak kosnya. Ia membuat peraturan yang harus dipatuhi. Sehingga anak-anak kosnya mulai terbiasa dan menghargai waktu. 
Ketujuh nilai empati, ditunjukan oleh sikap Ananda kepada anak-anak kosannya. Ananda yang mempunyai sikap tegas dalam hal ini mempunyai kelembutan hati dan peduli kepada anak-anak kosnya.

\section{DAFTAR PUSTAKA}

Dematra, Demian. (2010). Yogyakarta. Jakarta: Gramedia Pustaka Utama.

Moleong. L, J. (2011). Metodelogi penelitian kualitatif. Bandung: Remaja Rosdakarya.

Nurgiantoro, Burhan. (2015). Teori kajian fiksi. Yogyakarta: Gajah Mada University.

Zubaedi. (2010). Pendidikan berbasis masyarakat. Yogyakarta: Pustaka Pelajar.

Wellek, Werren. (2016). Teori kesusastraan. Jakarta: Gramedia Pustaka Utama. 